\title{
Increasing the Rate of Cattle Dung Decom- position by Nitrogen Fertilization
}

\author{
JOHN LUSSENHOP, D.T. WICKLOW, RABINDER KUMAR, AND J.E. LLOYD
}

\begin{abstract}
Cattle dung on a Colorado range was subjected to 6 years of irrigation and nitrogen fertilization. Disappearance of the dung was determined by sampling particles $>0.8 \mathrm{~cm}^{2}$. No particles remained in irrigated plots. Seventy-two percent less dung weight remained in nitrogen fertilized than in control plots. Nitrogen fertilization increased dung nitrogen concentration by $13 \%$. We argue that fertilization increased weight loss by stimulating microbial growth.
\end{abstract}

Can the rate of dung disappearance from arid rangeland be increased? Such increases would probably be beneficial, speeding nutrient cycling and releasing more space to plants (Marshall 1974, Marsh and Campling 1970). Disappearance of dung is ultimately the result of metabolic activities of microorganisms and associated microfauna. But decomposition is much slower than fragmentation of dung by rainfall or frost cracking (White 1960), or by such a nimal activity as trampling (Boswell and Smith 1976), foraging in dung (Anderson and Merritt 1977), or by burial by dung beetles and earthworms (White 1960). It is fragmentation rather than decomposition that results in rapid loss of dung in moist grasslands. This study focuses attention on decomposition in arid rangeland where fragmentation is slow, and where any factor which stimulates metabolic activity of decomposer microorganisms is likely to speed disappearance of dung. In the present study we demonstrate that nitrogen fertilization increases the rate of dung disappearance by increasing decomposer activity.

\section{Materials and Methods}

The research was performed on the Pawnee Site, the field research facility of the Natural Resource Ecology Laboratory, Colorado State University, located on the U.S. Dep. Agr. Agricultural Research Service Central Plains Experimental Range. Annual precipitation varies from 254 to $381 \mathrm{~mm}$, about $80 \%$ occurring from May to September (Dodd and Lauenroth 1979). During the growing season actual evapotranspiration nearly equals precipitation (Sims and Coupland 1979).

In 1970, a pasture which had been grazed for 10 years was fenced into eight 1-ha plots from which cattle were then excluded. The homogeneous population of dung particles remaining from 10 years of grazing was subjected to these singly replicated treatments: (1) irrigation sprinkling between 1 May and 1 September to maintain soil moisture tension $<0.8$ bars; (2) nitrogen fertilization (ammonium nitrate applied to maintain a $50 \mathrm{~kg} /$ ha difference between fertilized and unfertilized soil; (3) irrigation plus nitrogen fertilization; and, (4) an untreated control. The nitrogen fertilized

\footnotetext{
Authors are associate professor of biological sciences, University of llinois at Chicago Circle, Chicago, 60680; microbiologist, Northern Regional Research Center,

U.S. Dep. Agr., Agr. Res. Serv., Peoria, Ill. 61604; research associate and professor, Entomology Section, University of Wyoming, Laramie 82071

Authors thank D.C. Coleman, Natural Resource Ecology Laboratory, Colorado State University, for the soil nitrogen data, J.W. Waggoner and H.D. Radloff, Animal Science Division, University of Wyoming, for providing facilities to determine dung nitrogen. J.L. Moyes, S.E. Williams, and R.J. Lavigne critically read the manuscript. Research supported by NSF Grant DEB77-09443.

Manuscript received July $31,1980$.
}

plots are most important in the present discussion; in these plots $150 \mathrm{~kg} / \mathrm{ha}$ of nitrogen was applied in 1970 , and $100 \mathrm{~kg} / \mathrm{ha}$ in 1973 and 1974. The purpose of the treatments was to determine effects on plant species composition (Dodd and Lauenroth 1979). This objective did not interfere with our study of the 6 years of treatments on decomposition of cow dung remaining from the 10-year period of grazing.

We collected dung in November, 1976, by walking systematically over half of each plot, collecting all visible particles, the lower size limit being ca. $0.8 \mathrm{~cm}^{2}$. There was no indication of aggregation of dung in any of the plots. The particles were weighed after drying at $90^{\circ} \mathrm{C}$ for 48 hours. The $\mathrm{CO}_{2}$ absorption method of Lieth and Ouellette (1962) was used to determine microbial activity during the first 24 hours after wetting dry field-collected dung (2\% moisture) to $150 \%$. Composited samples were prepared for determination of total Kjeldahl nitrogen.

\section{Results and Discussion}

When irrigation and fertilization treatments were applied, dung had lain in the field at least 6 years. During this time pats lost

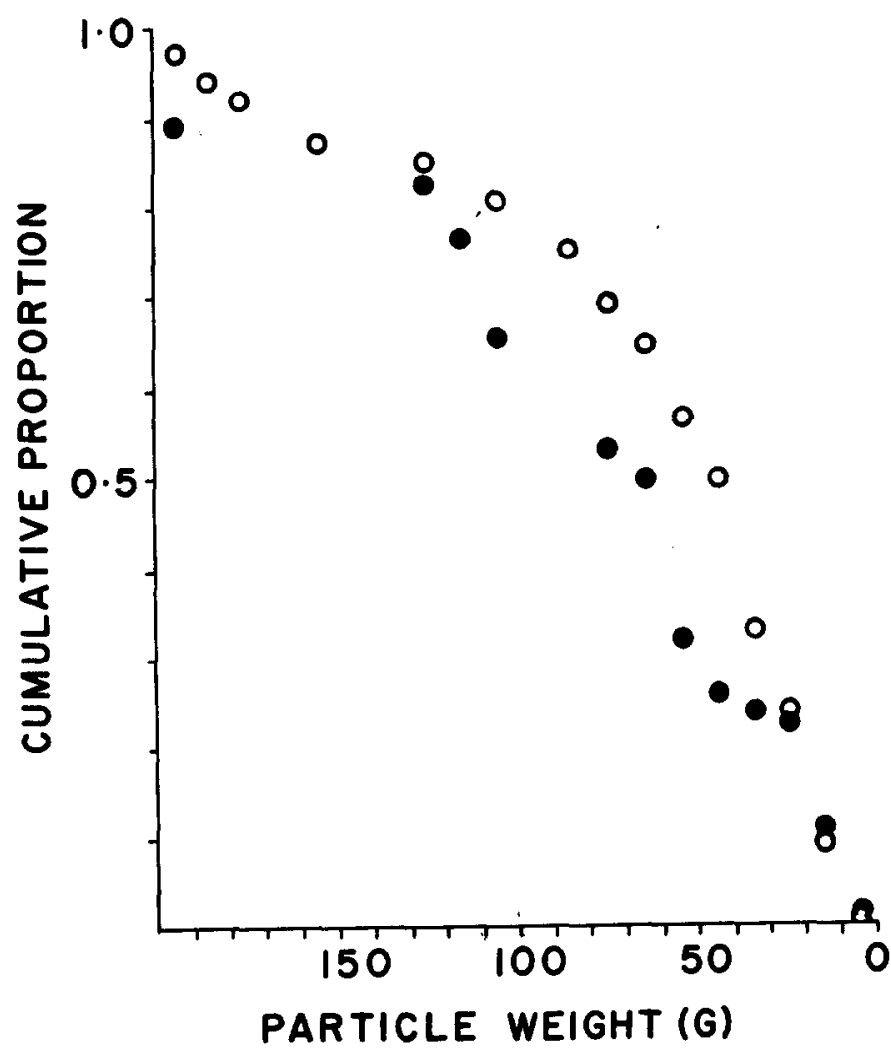

Fig. 1. The cumulative proportion of dung particles remaining in each 10 $\mathrm{gm}$ weight class from control $(0)$ and nitrogen fertilized plots ( $)$. 
Table 1. Density, abundance, and nitrogen content of cattle dung pats subjected to irrigation and nitrogen fertilization. Standard errors are given in parentheses; single and double asterisks indicate significant difference from the control at $5 \%$ and $1 \%$ levels respectively.

\begin{tabular}{lccccc}
\hline Treatment & $\begin{array}{c}\text { Total weight } \\
\left(\mathrm{gm} / \mathrm{m}^{2}\right)\end{array}$ & $\begin{array}{c}\text { Dung parti- } \\
\text { cles } / \text { ha }\end{array}$ & \multicolumn{2}{c}{$\%$ nitrogen } \\
\hline Irrigation & 0 & 0 & - & $0.11(0.04)$ \\
lrrigation + & & & & \\
$\quad$ Nitrogen & 0 & 0 & - & $0.16(0.04)$ \\
Nitrogen & $0.19(3.49)^{* *}$ & $23(3.7)^{* *}$ & $1.83(0.04)^{*}$ & $0.11(0.03)$ \\
Control & $0.68(1.72)$ & $74(2.9)$ & $1.62(0.05)$ & $0.12(0.04)$ \\
\hline
\end{tabular}

weight by respiration of decomposer organisms and both physical and biological forces caused their fragmentation. Important physical causes of fragmentation are drops of water and abrasion by windblown detritus. Plots were not sprinkled in spring or fall when freezing temperatures would cause frost cracking. Biological fragmentation may have been caused by plant growth in dung and by brief invertebrate tunneling. When collected, pats contained few individual insects and no termite or ant colonies.

Irrigation and irrigation plus nitrogen fertilization treatments result in rapid dung loss by the combination of physical and biological fragmentation. Compared with controls, irrigation increased weight loss by more than the $72 \%$ increases observed for nitrogen fertilization alone because no dung particles larger than $0.8 \mathrm{~cm}^{2}$ remained in irrigated plots.

The role of microbial growth in increasing fragmentation and weight loss is illustrated by the contrast between nitrogen fertilized and control plots. Nitrogen fertilized plots contained $72 \%$ less dung weight and $62 \%$ fewer dung particles than unfertilized plots (Table 1). Most dung particles were of intermediate weight so that a graph of the cumulative proportion of dung particle weights is convex (Fig. 1). White (1960, Table 4) obtained a similar distribution after fragmentation of sheep dung during a winter in England. Fertilization decreased the relative abundance of intermediateweight particles $(P<0.01$; Kolmogorov-Smirnov 2-sample test). The loss of intermediate-sized dung particles plus the lower number and weight of all particles implies faster fragmentation of nitrogen-fertilized relative to unfertilized dung.

We argue that the reason faster fragmentation rates occur in fertilized plots is because additional nitrogen allows more metabolically active microbial populations. Dung remaining in fertilized plots retains some fertilizer nitrogen (Table 1)-probably immobilized by microorganisms. This conclusion is supported by differ- ences in rates of $\mathrm{CO}_{2}$ evolution. During the first 24 hours aft wetting to $150 \%$ moisture, random samples of dung particles fro the fertilized plots released $\mathrm{CO}_{2}$ seven times faster than equal-size particles in samples from the control plots (14 vs $2 \mu \mathrm{g} / \mathrm{g} / \mathrm{hr} ; 1$-ws ANOVA, $p<0.05$ ).

In a similar nitrogen fertilization experiment, Castle and $\mathrm{Ma}$ Daid (1972) recorded time to crumbling and time to total disint gration of 228 marked dung pats in an English pasture. The applied nitrogen ( 22 or $90 \mathrm{~kg} / \mathrm{ha}$ ) in 6 monthly applications durir the grazing season for 2 years. The statistically insignificant tren they observed are consistent with the present study and might ha been significant if weight loss had been recorded. The arid site , the present study contrasts with the relatively humid study sites ، White (1960) and Castle and MacDaid (1972).

We conclude that in mesic grasslands dung disappears so rapid by physical and biological fragmentation that the effect of fertiliz tion is not observed. However, in arid ranges where the fragment; tion rate is lower, nitrogen fertilization increases th decomposition rate by stimulating microbial activity.

\section{Literature Cited}

Anderson, J.R., and R.W. Merritt. 1977. The impact of foraging meado larks, Sturnella neglecta, on the degradation of cattle dung pads. J. Ap] Ecol. 14:355-362.

Castle, M.E., and E. MacDaid. 1972. The decomposition of cattle dung a1 its effect on pasture. J. Br. Grassland Soc. 27:133-137.

Boswell, C.D., and A. Smith. 1976. The use of fluorescent pigment record the distribution by cattle of traces of feces from dung pats. J. I Grassland Soc. 31:135-136.

Dodd, J.L., and W.K. Lauenroth. 1979. Analysis of the response of grassland ecosystem to stress, p. 43-48. In: N.W. French, Ed. Perspecti in Grassland Ecology, Springer-Verlag, New York.

Lieth, H., and R. Ouellette. 1962. Studies on the vegetation of the Gas Peninsula. I1. The soil respiration of some plant communities. Can. Bot. 40:127-240.

Marsh, R., and R.C. Campling. 1970. Fouling of pastures by dung. Her Abstr. 40:123-130.

Marshall, J.K. 1974. Effects of stock on microenvironments in Australii rangelands, p. 167-185. In: Plant morphogenesis as the basis for scienti management of range resources: Proceedings of the workshop of $t$ United States-Australian Rangelands Panel, U.S. Dep. Agr., Agr. R, Serv., Misc. Pub. 1271.

Sims, P.L., and R.T. Coupland. 1979. Producers, p. 49-72. In: R.T. Cou land, Ed., Grassland Ecosystems of the World: Analysis of Grasslan and Their Uses, Cambridge Univ. Press, New York.

White, E. 1960. The distribution and subsequent disappearance of she dung on pennine moorland. J. Anim. Ecol. 29:243-250. 